\title{
The Effect of Experimental 17-beta Estradiol Administering on Calcium Metabolism Regulation in Young Laying Hens
}

\author{
Nicolae DOJANA ${ }^{1 *}$, Gabriel COTOR ${ }^{2}$, Iuliana CODREANU ${ }^{1}$, Rosalie BĂLĂCEANU ${ }^{2}$ \\ ${ }^{1}$ Department of Physiology, \\ ${ }^{2}$ Department of Physiopathology, Faculty of veterinary Medicine, U.S.A.M.V., Independentei str., 105, \\ 050097 Bucharest, Romania \\ Corresponding author: dojana2001@yahoo.com \\ Bulletin UASVM Veterinary Medicine 72(1) / 2015, \\ Print ISSN 1843-5270; Electronic ISSN 1843-5378 \\ DOI:10.15835/buasvmcn-vm: 10854
}

\begin{abstract}
Three groups of 128-day-age laying hens were i.m. injected with 17-beta estradiol for eight days, in different doses, vs. an untreated control group. Calcium from ingesta, egg shell, feces and mineral bone content was determined. At the end of the experimental treatment, the results showed an increase in the egg yield in all treated hens vs. control, between $6 \%$ and $8 \%$ depending on the estradiol dose, but not proportionally to the dose of estrogen administered. The amount of daily absorbed calcium was (in g): 0.97 in control while in estrogen treated groups the values ranged between 1.37 and 1.77. Calcium concentration of the egg shell and total calcium content of the egg shell was not significantly influenced. The daily mean amount of calcium excreted by egg was increased vs. control. Blood calcium values ranged between 5.65 and $7.16 \mathrm{meq} / 100 \mathrm{~mL}$ vs. $4.45 \mathrm{meq} / 100 \mathrm{~mL}$ plasma in control $(\mathrm{P}=0.0081)$. The amount of the mineral content of the bone increased while calcium excreted in the feces and urine was less than in control. Blood levels of calcitonin, parathormone, progesterone and calcitriol were found modified, relatively proportional to the administered amount of estrogen.
\end{abstract}

Keywords: calcium metabolism regulation, estradiol, laying hens.

\section{INTRODUCTION}

Calcium metabolism regulation in laying hens involves a complex of biochemical, nervous and hormonal factors. One of these factors is represented by the estradiol. Usualy it is accepted that estradiol is sinergic to parathormone in laying hens but the exact role of this hormone in the regulation of the calcium metabolism in laying hens isn't well understood (Hafez, 1993; Bentley et al., 1998; Dojana et al., 2014).

\section{AIMS}

The aim of this research was to find out the exact role of the estrogen in the regulation of the calcium metabolism in laying hen at the beginning of the laying cycle, when a lot of hormonal events develops according to the installation of the puberty and the starting of the laying cycle.

\section{MATERIAL AND METHODS}

Three group of 128-day-age ROSSO laying hens noticed as A, B and C were i.m. injected with 17-beta estradiol in different doses (IU/cap./day): 12,500 in group A, 25,000 in group B and 50,000 in group C. The all experimental treatment lasted for 8 days. Calcium content form ingesta, egg shell, feces and mineral bone content were determined in the three experimentally treated groups vs. an untreated control group. Fodder, feces, eggshell and bone samples were calcinated at $500^{\circ} \mathrm{C}$. Calcium from the resulted mineral samples was analyzed according to Predtecenschi et al. (1953) cited by 
Tab.1. Blood plasma levels of the main hormones involved in regulating of calcium metabolism in ROSSO hens, 128 days aged, treated with 17-beta estradiol for 8 days (pg/mL)

\begin{tabular}{cccccc}
\hline Hormone & Control & Group A & Group B & Group C & P (ANOVA) \\
\hline Calcitonin & $220.5 \pm 12.0$ & $230.0 \pm 19.0$ & $234.8 \pm 14.0$ & $226.1 \pm 22.2$ & 0.0390 \\
\hline Parathormone & $77.9 \pm 3.2$ & $55.5 \pm 4.3$ & $44.5 \pm 3.5$ & $40.0 \pm 2.4$ & 0.0492 \\
\hline Progesterone & $30.0 \pm 2.8$ & $67.8 \pm 4.5$ & $73.5 \pm 4.4$ & $81.9 \pm 5.5$ & 0.0018 \\
\hline Calcitriol & $140.5 \pm 7.0$ & $178.5 \pm 15.5$ & $166.6 \pm 11.0$ & $190.5 \pm 16.5$ & 0.0098 \\
\hline
\end{tabular}

Manta (1976). The plasma levels of estradiol and the main hormones potentially involved in the calcium metabolism regulation were measured at the end of the experimental treatment period for the experimental and control groups using a COBAS e 411 ANALYZER. The results were processed statistically by ANOVA-single-factor test and the null hypothesis was rejected for $\mathrm{P}<0.05$.

\section{RESULTS AND DISCUSSION}

According to the results, it was found an increase in the egg yield of estradiol-treated hens vs. control, between $6 \%$ and $8 \%$ depending on the group, not proportionally to the dose of estrogen administered.

The amount of daily absorbed calcium was (in g): 0.97 in control while in estrogen treated groups the values were 1.37 (group A), 1.54 (group B) and 1.77 (group C). Estrogen treatments did not significantly influence the concentration of calcium in the egg shell or calcium content per whole egg shell. The daily mean amount of calcium lost was (in $\mathrm{mg}$ ): 528.5 in group A, 487.2 in group $B$ and 468.2 in group $C$ vs. 405.0 in control $(\mathrm{P}=0,0250)$. Blood calcium values ranged between 5.65 and $7.16 \mathrm{meq} / 100 \mathrm{~mL}$ vs. $4.45 \mathrm{meq} / 100 \mathrm{~mL}$ plasma in control at the end of the experimental period $(\mathrm{P}=0.0081)$. The amount of daily absorbed calcium ranged between 1.37 and 1.77 in experimentally treated groups vs. 0.97 in control. Calcium excreted in the feces and urine was (in mg/g dry matter of feces) was as it follows: 1.87, 1.68 and, respectively, 1.60, vs. 2.15 in control. The mineral content of the bone was $390 \mathrm{mg}$ ash/g of calcinated tibia bone in control vs. 439, 472 and, respectively, $460 \mathrm{mg}$ ash/g of tibia bone in experimental treated groups $(\mathrm{P}=0.0332)$. Regarding bone mineral content, Barr and Hurwitz (1987) reported values of $2.830 \mathrm{mg} /$ tibia bone in chickens and 2,250 mg / tibia bone in hens fed by low calcium diet. Beighle et al. (1995) reported content amounted to $59.2 \%$ of ash in the ribs of cow. Blood levels of calcitonin, parathormone, progesterone and calcitriol were found modified, according to the data from Tab.1. It was found a high level of calcitriol in the estrogen treated groups, which is in agreement with Gallagher et al. (1990): in birds, estrogen administration increases the conversion of calcidiol in calcitriol. According to some research data, the estrogen hormones are not considered traditionally calcitropic hormones because their influence on extracellular calcium appears to be more indirect, although they are directly involved in calcium homeostasis in a number of vertebrate species. In avian species, however, calcium homeostasis is closely related to ovulation and reproductive hormones. Onset of sexual maturity in White Leghorn laying hens increases plasma estradiol levels, total blood calcium and duodenal absorption of calcium (Hurwitz et al., 1973; Elaroussi et al., 1993, cited by Hansen, 2003). Many researchers including Corradino et al., 1993; Bluhm et al., 2003; Hansen, 2003; Senior, 2004 reveals effects of estrogens on intestinal epithelium, as direct stimulation of calcium absorption, or stimulatory effects on the secretion of other hormones, such as calcitriol.

\section{CONCLUSION}

Experimental estrogen treatement showed the involvement of this hormone in the regulation of the calcium metabolism in laying hens, being responsible for an increase in calcium absorption, an increase of eggshell calcium exports and an increase of calcium deposition in bones. Blood plasma levels of calcitonin, parathyroid hormone, progesterone and calcitriol are modified accordingly. 


\section{REFERENCES}

1. Bar A, Hurwitz S (1987). Vitamin D Metabolism and Calbindin (Calcium-Binding Protein) in Aged Laying Hens. The Journal of Nutrition $1775-1779$.

2. Beighle DE, Boyazoglu PA, Hemken RW, Serumaga-Zake PA ( 1994). Determination of calcium, phosphorus, and magnesium values in rib bones from clinically normal cattle. Am J Vet Res Jan 55(1):85-9.

3. Bentley PJ (1998). Comparative Vertebrate Endocrinology. Cambridge, UK, CambridgeUniv Press, 269-301.

4. Bluhm CK, Phillips RE, Burke WH (2003). Serum levels of luteinizing hormone (LH), prolactin, estradiol, and progesterone in laying and nonlaying canvasback ducks (Aythya valisineria). General and Comparative Endocrinology 52(1):1-16.

5. Dojana N et al.(2014). Tratat de fiziologie animală și etologie. Editura Printech, Iasi.

6. Corradino RA, Smith CA, Krook LP, Fullmer CS (1993) Tissue- specific regulation of shell gland calbindin D28K biosynthesis by estradiol in precociously matured, vitamin D- depleted chicks. Endocrinology 132:193-198.
7. Gallagher JC, Riggs B L, DeLuca H. F. (1990). Effect of Estrogen on Calcium Absorption and Serum Vitamin D Metabolites in Postmenopausal Osteoporosis. Journal of Clinical Endocrinology and Metabolism 51(6):1359.

8. Hafez ESE (2003). Reproduction in farm animals. $6^{\text {th }}$ Edition, Lea \& Febiger Ed.

9. Hansen K (2003). Aging and the role of estrogen in calcium mobilization in the laying hen. ETD collection for University of Nebraska - Lincoln. Paper AAI3045518.

10. Manta I, Cucuianu M, Benga G, Hodârnău A (1976). Metode biochimice in laboratorul clinic. Dacia, Bucharest, Romania.

11. Preda Cl (2014) Particularities regarding the calcium metabolism regulation during the laying cycle in hen. U.S.A.M.V. Bucharest, PHD Diss, Bucharest, Romania.

12. Senior BE (2004). Oestradiol concentration in the peripheral plasma of domestic hen from 7 weeks of age until the time of sexual maturity. J Reprod Fertil (1)41:107-112. 